\title{
Packaging design strategies for introducing whole mealworms as human food
}

\author{
Saara-Maria Kauppi ${ }^{1}$ \\ ${ }^{1} N T N U$ \\ saara.m.kauppi@ntnu.no
}

\begin{abstract}
(300-500 words)
Consumer research has proposed strategies to introduce insects to Western consumers and packaging design could be seen as one of the strategies to promote insect-eating. This article discusses the variety of packaging design strategies for mealworms, Tenebrio molitor, based on packaging design suggestions by master's students. The design suggestions are analysed and categorised under different themes for introducing mealworms for Western consumers. The results are then discussed in the context of existing knowledge for marketing insects, contributing to the field on edible insects from a design perspective.
\end{abstract}

Keywords: packaging, communication, sustainability, edible insects, consumer acceptance

\section{Introduction}

Recent research has proposed insects as sustainable animal protein, mainly due to environmental benefits, since insects require considerably less feed (Collavo, 2005), water (Miglietta et al., 2015) and rearing space (Van Huis, 2013) and emit fewer greenhouse gases (Oonincx et al., 2010) than other animal-based protein sources on land. Insects are efficient to farm, as they gain their full body weight within a few months of time and can then be used for food (Van Huis, 2013). Moreover the nutritional benefits of insects are well established, they are relatively low in fat, high in protein and contain micronutrients valuable for human nutrition (Van Huis, 2013).

Consumer research has attempted to identify possible early adopters in the West $\left.{ }^{1}\right]$ by understanding what motivates people to eat insects. Much research has proposed strategies to overcome barriers to eating insects, but the majority of people in the West are still not ready to add insects to their daily diets. Design interventions, especially packaging design, can be targeted towards prospective consumer groups, for example early adopters, which can consequently aid the promotion of novel food products in the supermarket (Kauppi et al., 2019). The purpose of this paper is to investigate packaging design as a medium for discussing

\footnotetext{
${ }^{1}$ In this article the term West covers geographic entities of Europe, North America and Australia-New Zealand, where entomophagy - insect eating - practice have been less dominant in recent years (van Huis et al. 2013).
} 
promotional strategies for introducing mealworms as food. The main objective of this article will be to answer the following question: What kinds of packaging design strategies could be used for promoting mealworms? To answer this question, the results of packaging design suggestions by design students will be presented and analysed.

\section{Background: Consumer acceptance, packaging design and strategies}

The current consumer research introduces a variety of strategies for adopting insect-eating. Drawing from the literature review on consumer acceptance of insects by Mancini et al. (2019), the most important drivers of consumers choosing to eat insects are sociocultural and psychological background. In addition, familiarity, visibility, taste and price of insects are also factors that influence consumers' choice (Mancini et al., 2019). Looking at strategies to promote insects, the literature suggests sensorial, marketing and educational-focused strategies. However, design-focused strategies could be given more focus in the consumer research (Kauppi et al., 2019). Consumers are often willing to try whole insects or insect-based foods, but integrating insects into their daily diet in the long-term is still challenging (Kauppi et al., 2019, House, 2018). To gain routinised consumption of insect-based foods, several factors influencing long-term consumption should be taken into consideration (House, 2016). These factors combined with a framework for acceptance of edible insects (Figure 1.) build a starting point for further elaboration of packaging design strategies for insect food.

\section{Consumer acceptance research}

1) THE CONSUMER

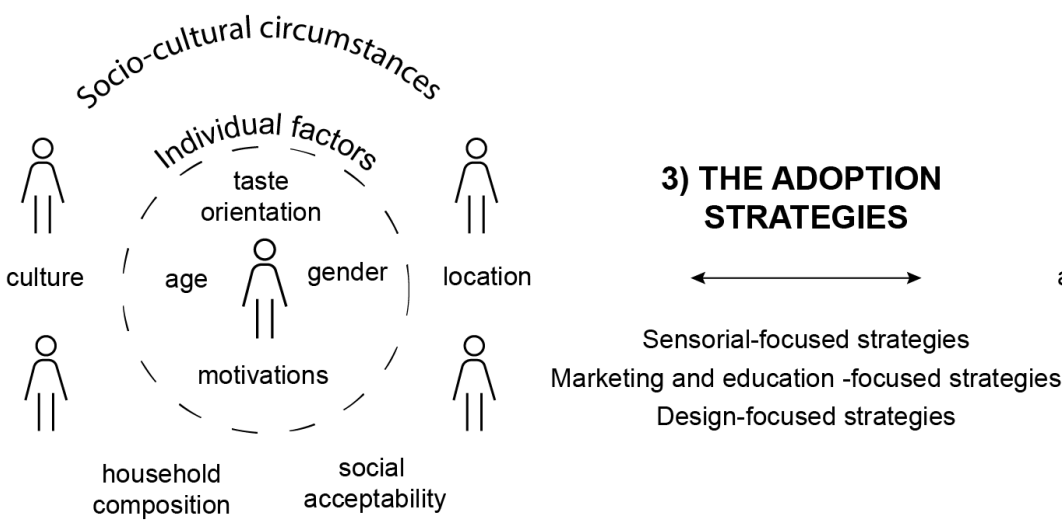

2) THE PRODUCT

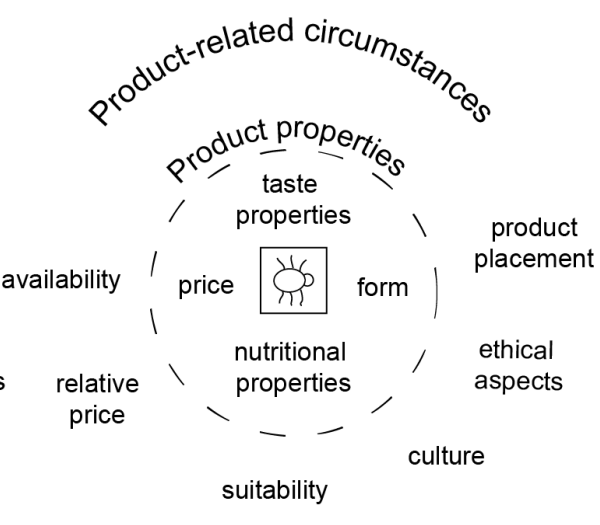

Figure 1. Framework for understanding consumer acceptance of insects Kauppi et al. (2019).

The framework (Figure 1) connects the findings in the literature about the consumer (1), the product (2) and the adoption strategies (3) to understand the acceptance of insects. The literature suggests some concrete marketing tactics for insects, for example it is suggested to use euphemisms such as 'land shrimp' for grasshoppers or scientific names such as 'molitor' for mealworms for introducing insects (Shelomi, 2015). It is important to provide information and teach consumers about insect-eating (Lensvelt and Steenbekkers, 2014) and to understand eating practices of consumers (House, 2018a). Seducing consumers for exotic food experiences and healthy eating could be part of successful strategies (Deroy et al., 2015) as well as promoting insects to the early adopters with experimental taste orientation (Verbeke, 2015). In addition to these singular findings, the full acceptance and routinised consumption of insects will likely be an interplay of various factors, and it will require a comprehensive understanding of the practices of food consumption and social factors influencing them. As food choice is understood to be a complex mix of sensorial, situational, social, cultural, demographical and 
cognitive factors (Tan, 2017, Verneau et al., 2016, Lensvelt and Steenbekkers, 2014, Looy \& Wood, 2006), a combination of factors may offer the best potential for successful long-term adoption. As a contribution to the adoption of insects as food, packaging design could be regarded as part of the process by influencing the purchase decision at retail setting.

\section{Packaging design and consumption}

Packaging is described as 'the silent salesman' (Pilditch (1961) that creates an identity to the product and is tightly interconnected with it. The term packaging design in this article is mainly used for discussing the use of graphic design linked to the promotion of convenience products. Design helps the product stand out in the supermarket, promote a desirable price range, advertise the brand and inform the consumer visually and textually about the product. Most of the buying decisions for daily groceries are made in-store, of which $90 \%$ of the products are purchased while consumers have only looked at the front of the packaging (Clement, 2007). This shows that consumers are most influenced by the product packaging when they make buying decisions, which stresses the key role of packaging in a supermarket setting (Ampuero, 2006, Rundh, 2005, Rundh, 2009). Important elements that influence the appearance of packaging are shape, texts, size, colour, texture and graphics (Ampuero, 2006, Rundh, 2005, Rundh, 2009). For example, colour can be the trademark of a brand and therefore create meaning, or it can create expectations of certain flavours (Madden, 2000, Piqueras-Fiszman and Spence, 2011);due to their high noticeability, graphics can make the difference between noticing or missing the product (Silayoi and Speece, 2007). Gaining an emotional connection between the packaging and the consumer is especially important in novel, unfamiliar products such as edible insects, as people have less connection to these products (Heiskanen et al., 2007).

\section{Meaning of packaging design}

Packaging design increases the value of a product being noticed in the supermarket and the visual elements can be designed to target the most suitable consumer groups by using graphic design principles (Kauppi et al., 2019). Drawing from theory about the meaning of packaging, the packaging does not only reflect the product, but also presents experiential, functional and symbolic benefits for the consumer (Underwood, 2003). For example, packaging design can trigger emotions (experiential), it has a certain way of performing in consumer use (functional) and may represent something more abstract such as brands or ideologies (symbolic). There are many ways to promote insect-based products and whole insects to consumers, for example, packaging design could be linked to functional benefits such as linking the product into existing cooking practices. Packaging can be employed to offer information about the benefits of insectbased food or reflect a product's symbolic benefits such as sustainability or healthy lifestyle, and to promote nutritional values that consumers find important. The graphic design elements such as illustrations could then trigger experiential benefits, such as joy or even the adventure of insect-eating.

\section{Packaging design and insect-based products}

Consumer studies suggest that information on nutrition (Schouteten et al., 2016) and sustainability benefits (House, 2016), as well as having affective emotion-based communication (Onwezen et al., 2019), have positive effects on consumers regarding insecteating. One study on visual perception of edible insects suggests that textual information accompanied with visual images performs well in a restaurant setting, where people usually take more time to read the descriptions (Baker et al., 2016). Whereas in retail setting, where consumers have less time and more options, they base their decision on visual cues and less on the textual description (Baker et al., 2016). The current research consensus on edible insect consumer acceptance 'hidden works the best' should be revaluated considering the type of food, 
the method, consumer profiling and social context that the consumer studies take place (House, 2018b). Some rules for showing the insects from a graphic design point of view can be described. Firstly, whether or not insects are perceived visually unappealing depends on the composition of all the visual elements on the packaging (Kauppi, 2016). This means that the other ingredients displayed visually (e.g. nuts or herbs) may help insect-based product being perceived as tasty. Secondly, the visual perception of insects is depended on the product and packaging's overall visual composition, for example a realistic illustration of close-up image on insect head creates an impression of pesticide rather than food (Kauppi, 2016).

\section{Case study: Packaging design strategies}

\section{Description of the course work}

The designs were created by master's students at NTNU Institute of Design as a course assignment for a packaging course in 2018. The course was a collaboration with NTNU and a Norwegian mealworm producer, Larveriet. The author worked as a lecturer during the course and the students agreed that their designs could be used as part of the international research project. Larvariet made a separate contract with the students regarding the possible commercialisation of the designs taking place after the course.

Larveriet's design brief consisted of designing a label for $15 \mathrm{~g}$ of whole dried mealworms in a paper pouch. The design brief was fairly open, leaving multiple possibilities for the students' own considerations and exploration such as the target audience and material for the label. However, some limitations were given: the size of the paper pouch was fixed $(130 \mathrm{~mm} \times 200$ $\mathrm{mm}$ ) and the type of the pouch was preselected. The product name 'Mjølmums frå Voss' and producer Larveriet were assigned to be placed on the label. The students had seven weeks to create two designs under the same brand, for $15 \mathrm{~g}$ regular mealworms, a $5 \mathrm{~g}$ pouch of chilli flavoured mealworms and a cardboard distribution package for both sizes. This article looks at the $15 \mathrm{~g}$ pouches, leaving out the $5 \mathrm{~g}$ chilli variant and the cardboard boxes in order to reduce complexity. Altogether 24 different designs were analysed and categorised into a variety of strategies to promote mealworms.

\section{Description of the design analysis}

Firstly, all designs were described by the author by looking at the visual cues, text, used imagery and interpreted meaning. Secondly, the descriptions were compared with students' own description for expanding the core idea of the design. The aim of the description was not to compare the descriptions written by the students and interpreted by the author, but to make sure that the students' ideas for the designs were properly understood by the author. Finally, the descriptions of the designs were exported to NVivo for further analysis to find frequencies and differences between them. 


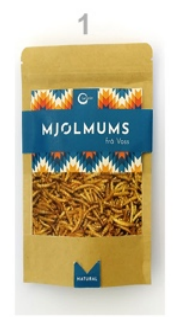

9

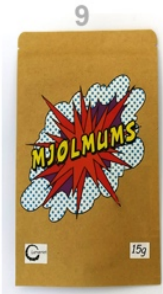

17

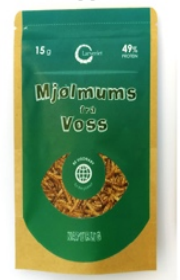

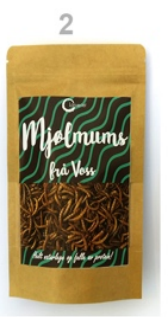

10

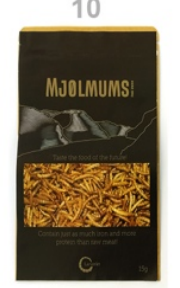

18

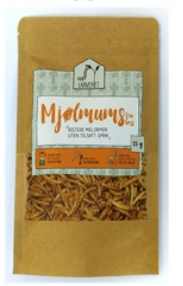

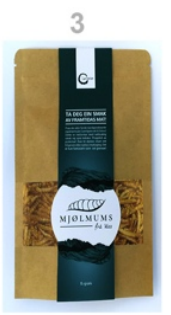

11

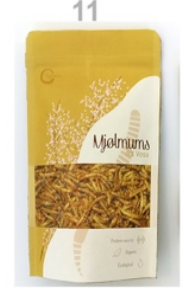

19

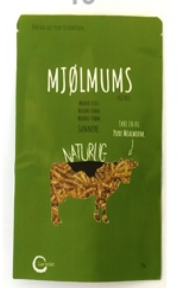

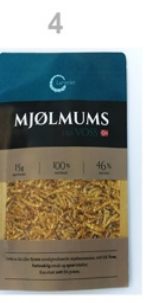

12

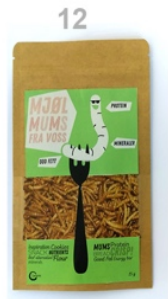

20

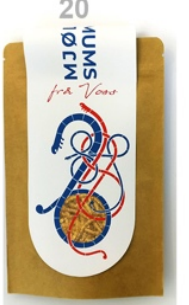

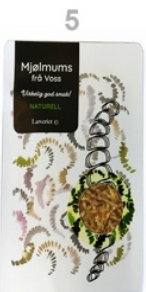
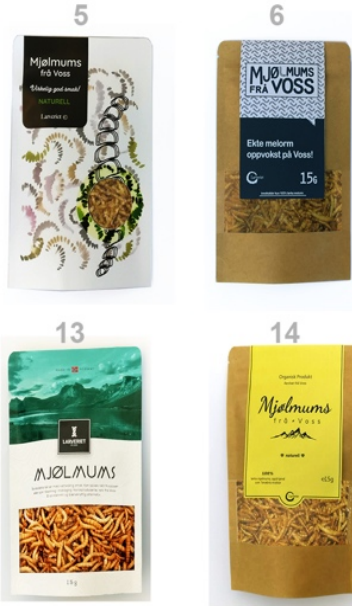

21

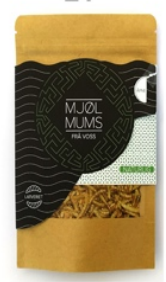

22
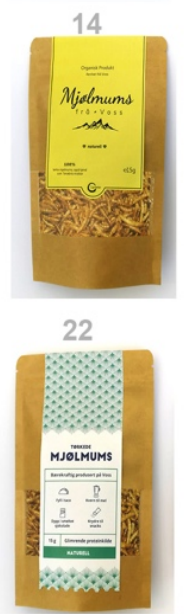
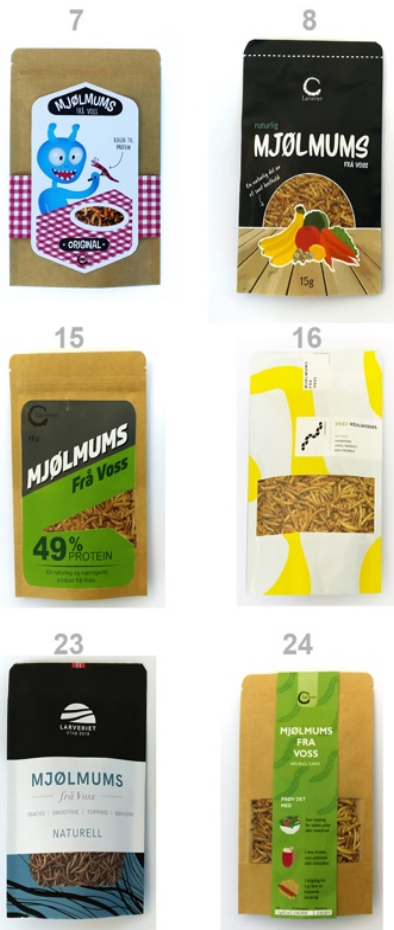

Figure 2. The designs of labels for mealworms by 2nd year master's students in product design at NTNU.

\section{Results}

The results can be divided into two categories: firstly, the graphic design choices students used for the design task and secondly, the symbolic meaning of their designs. The first part describes the individual choices with regards to graphic design, analysing the contradictions and also the collective similarities of the designs. The second part discusses more about the design as a whole, the meaning and the themes students wanted to achieve with their choices in graphic design.

\section{Graphic design choices}

16 students out of 24 reduced the window size by designing the label over the window, leaving less space for visible mealworms. 8 of those 16 students used worms as a source of inspiration in their patterns and illustrations. It could be interpreted that covering the window was used as part of the design, making the shape of the label more interesting, and not necessarily as a deliberate choice to reduce visible mealworms. Half of the students were inspired by the mealworms to design 'wormy' patterns and illustrations on the label. 9 out of 24 challenged the design brief by designing a label that covered the whole packaging, exceeding the limitations given by the company. The most commonly used category of typeface was sans serif for the brand text, although some students were also inspired by curly script fonts that imitated handwriting. Darker colours were mostly used for achieving a premium effect accompanied by a couple of exceptions with a white background also aiming for a premium impression of the product (Figure 2, design 13 and 16). 
Table 1 Design strategies for promoting insect-eating. The designs were given numbers 1-24, and each of them were analysed for symbolic meanings, hence the design strategies they represented. The numbers on the right indicate how many designs repeated the same strategy.

\begin{tabular}{|c|c|c|c|c|c|c|c|c|c|c|c|c|c|c|c|c|c|c|c|c|c|c|c|c|c|}
\hline & $\mathrm{van}$ & $\omega$ & & & 줌 & $m$ & - & cin & & & 4 & 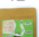 & 0 & & 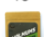 & 71 & & & & is & & $\ldots$ & - & 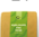 & \\
\hline $\begin{array}{l}\text { Exotic food, influence } \\
\text { from other cultures }\end{array}$ & $\mathrm{x}$ & & & & & & & & & & $x$ & & & & & & & & & & & & & & 2 \\
\hline Playfulness & $\mathrm{x}$ & $\mathrm{x}$ & & & & & $\mathrm{x}$ & & & & & $x$ & & & & $x$ & $\mathrm{x}$ & & & & & & & & 6 \\
\hline Natural & & & $\mathrm{x}$ & & $\mathrm{x}$ & & & & & & $x$ & & & & & $x$ & & & & & & & & $\mathrm{x}$ & 5 \\
\hline Local food (Norwegian) & & & & $\mathrm{x}$ & & & & & & & & & $\mathrm{x}$ & $x$ & & & & & & $\mathrm{x}$ & & & & & 4 \\
\hline Artistic & & & & & $\mathrm{x}$ & & $\mathrm{x}$ & & $\mathrm{x}$ & & & & & & & & & & & & & & & & 3 \\
\hline Experimental & & & & & $\mathrm{x}$ & & $\mathrm{x}$ & & $\mathrm{x}$ & & & & & & & & $\mathrm{x}$ & & & & & & & & 4 \\
\hline Trendy, modern design & & & & & & $\mathrm{x}$ & & & & & & & $x$ & & & $\mathrm{x}$ & & $\mathrm{x}$ & & & & & $\mathrm{x}$ & & 5 \\
\hline Simplistic & & & & $\mathrm{x}$ & & $\mathrm{x}$ & & & & & & & & & & & & & & & & & $x$ & & 3 \\
\hline Normalisation & & & & & & & & $\mathrm{x}$ & & & & & & $\mathrm{x}$ & & & & $\mathrm{x}$ & $\mathrm{x}$ & & & $\mathrm{x}$ & & $\mathrm{x}$ & 6 \\
\hline $\begin{array}{l}\text { Educative, usage, } \\
\text { Cooking suggestions }\end{array}$ & & & & & & & & & & & & & & & & & & $x$ & & & & $\mathrm{x}$ & & $\mathrm{x}$ & 3 \\
\hline Premium & & & $\mathrm{x}$ & $x$ & & & & & & $\mathrm{x}$ & & & $x$ & & & & & & & & $x$ & & $x$ & & 6 \\
\hline Handicraft & & & & & & & & & & & $\mathrm{x}$ & & & & & & & & & & & & & & 1 \\
\hline For kids & & & & & & & $\mathrm{x}$ & & & & & $\mathrm{x}$ & & & & & & & & & & & & & 2 \\
\hline $\begin{array}{l}\text { For fitness, emphasis } \\
\text { on nutrion }\end{array}$ & & & & & & & & & & & & & & & $\mathrm{x}$ & & & & & & & & & & 1 \\
\hline Future oriented & & & & & & & & & & & & & & & & & $\mathrm{x}$ & & & & & & & & 1 \\
\hline Traditional & & & & & & & & & & & & & & & & & & & & $\mathrm{x}$ & $\mathrm{x}$ & & & & 2 \\
\hline $\begin{array}{l}\text { Empowering } \\
\text { consumers }\end{array}$ & & & & & & & & & & & & & & & & & $x$ & $x$ & & & & & & & 2 \\
\hline $\begin{array}{l}\text { Environmental } \\
\text { benefits }\end{array}$ & & & & & & & & & & & & & & & & & & & $\mathrm{x}$ & & & & & & 1 \\
\hline
\end{tabular}

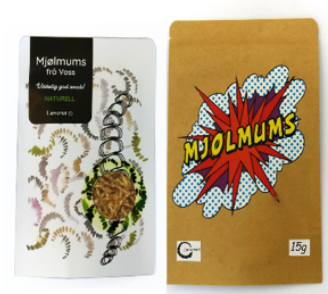

Experimental artistic approach (a)

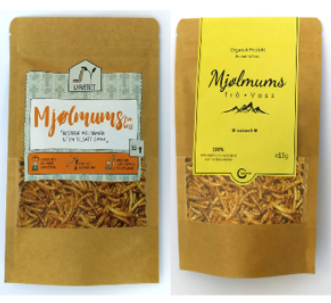

Narmalising insects, refering to flour (f)
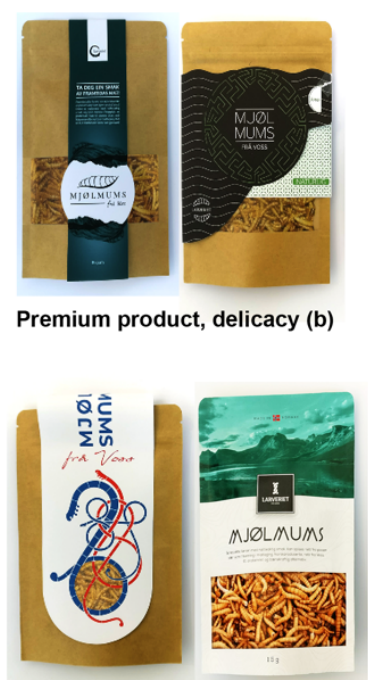

Origin oriented, local product from Norway (g)

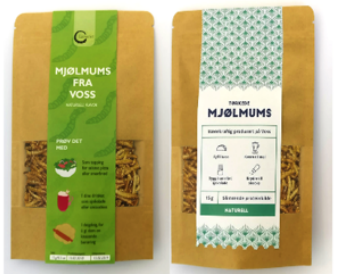

Promoting cooking suggestions (c)

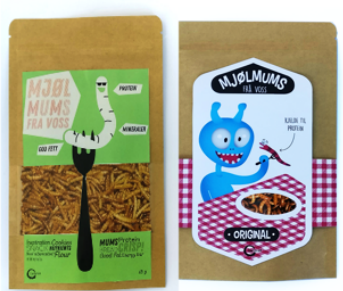

Normalising insects with Western eating habits I Insects for kids (h)

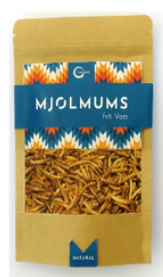

Cultural (Latin) influence (d)

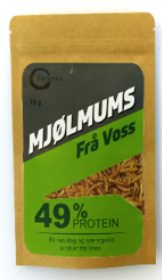

Nutritional values (i)

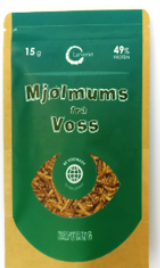

Future oriented \& empowering consumers (e)

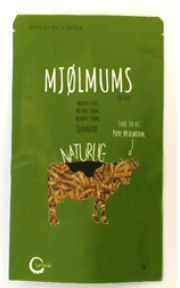

Sustainability I Refering to other animal meat (j)

Figure 3 Examples of design strategies for mealworm promotion. 


\section{Symbolic meanings}

Figure 3 showcases some of the strategies using symbolic meaning for promoting mealworms. These strategies are targeted to different consumer groups and the products could be sold in specific places to reach their potential target consumers. For example, the design in the category experimental artistic approach (Figure 3. a) could be sold in art museums' shops, whereas the design promoting nutritional values (i) could be sold at gyms. Most of the students used multiple strategies in one label design to make the packaging appealing for prospective consumers, for example the students used ideas such as playfulness, normalisation (f) and premiumness (b) as part of the overall design strategy (See also table 1). Normalisation in this case means drawing visual analogies to other well-known food products such as flour or oats and making the design of the packaging resemble those products. Many of the students wanted to create a premium look, because the price of the product was relatively high. Another strategy promoted exotic eating (d) of insects, drawing ideas from cultures that normally use insects as food. These products promoting insects as exotic food with cooking suggestions could be placed with other non-Western food items in the supermarket. Using icons to visualise the preparation of insects, reflects the idea that packaging design can be visually linked to eating practices (c). Insects could also represent consumer empowerment (e), suggesting consumers make a difference for the future by choosing insects over other animal meat. Connecting insects with Western eating habits ( $h$ ) could be done by using Western food props such as the fork to make it visually clear that insects can be used as food in the West among with promoting locality of the food $(g)$ to avoid some consumers' risk aversion towards foreign food. Lastly, eating of insects can be promoted through its environmental benefits (j), by comparing them with other types of animal protein and through their nutritional values (i), promoting insects as functional food that has been suggested in the earlier literature.

\section{Discussion}

Interesting and perhaps useful commercial results from this design exercise occur when looking at the overall design strategies for convincing consumers. As insect-eating in the West is not fully conventionalised, therefore multiple design strategies for promoting insects can be seen in use. In comparison to other conventional animal products, such as milk or meat, promotional strategies for those products are rather limited. For example the visual imagery on milk usually promote naturalness, the package may have a cow or splash of milk visualised on it, whereas such obvious visual conventions are still lacking for insects, which makes design research on edible insects an interesting and acute topic.

The student designs reflect partially what can be found in the literature. Surprisingly, the benefits of eating insects and nutritional facts were less utilised by the students. One reason could be that for this design task students were not required to do an extensive research on the topic. Students were provided with lectures of insect-eating by the author, accompanied with the company's lecture on mealworms, but the students were not solely encouraged to visually replicate the current consumer knowledge from the literature. Moreover, the overarching design task was to design a label what the students think could work for the target group they personally selected and explore barriers and possibilities within those limits, as the design brief remained fairly open. The reason for an open design brief was to expand marketing possibilities through design exploration. Students got visually excited by mealworms resulting in wormy patterns and illustrations and as a group they paid less attention to the key claims for insect-eating as text as they unintentionally emphasised the imagery part in their designs. This finding could imply that a useful selling factor for insects indeed could be 'excitement' especially in the 
beginning of the promotion when the product is being introduced for the first time. This is in line with the literature that highlights the problem of long-term adoption as consumers have a hard time to include insects in their diet in a routinised way. Consumers are however, willing to try insects once or twice. This notion could be used in packaging design even more extensively to excite consumers to try insects, then later using strategies to engage with eating of insects for long-term use.

The design results lacked critical design approaches, questioning the idea of eating insects, mostly due to the fact that there was a real client that examined the design work. Having a real client gave students an extra element of stress and guided the design motives more into commercially feasible solution. However, a positive factor was the students were highly motivated to work with a real client than a hypothetical course assignment that was confirmed in the feedback. They felt their efforts were rewarded with a sense of a purpose as the designs were assigned to real use.

Some of the symbolic meanings of the packaging ideas can be found in the current commercial insect products. However, this may be the first time that packaging design strategies for mealworms, Tenebrio molitor, are compared and discussed at once. Having similar promotional ideas as those on the market, stresses the fact that companies look for multiple ways to promote insect-eating, but perhaps have not found the best practice yet. This exercise also visualised multiple ideas that have been reflected in the literature, but have not been actualised. The study can be viewed as a contribution to consumer research as it emphasises the practical examples of marketing strategies in use. Some practical tips can be given from this design exercise. Firstly, it is important to make the consumers notice the product and make them excited about it. Secondly, including visual and textual cues, in this case pictograms and recipes on preparing insects might make consumers engage with insects for routinised consumption. Thirdly, including cultural engagement with insects rather than technological aspects on food could work as a strategy. Using icons as cooking instructions or pictures of insect-based dishes could be an effective way to promote insects for consumers that need more guidance and inspiration for preparing insect-based food. Moreover, the role of packaging could therefore transform from 'a silent salesman' to 'a silent teacher' for aiding the adoption of novel, more sustainable foods.

\section{Conclusion}

Insects have potential as a novel food source because of their environmental and health benefits, but research on commercialising insect food is still in its early stages. This article discusses packaging as a medium for different promotional strategies for insects and builds on the understanding of how packaging design can be a catalyst for the marketing of novel foods. 24 packaging designs for dried whole mealworms, Tenebrio molitor, are analysed and categorised into themes for marketing insects. This design exploration can be helpful for companies working with edible insects, or with other novel protein, for looking into the various ways of marketing novel foods.

\section{References}

AMPUERO, O. 2006. Consumer perceptions of product packaging. Journal of Consumer Marketing, 23, 100-112. 
BAKER, M. A., SHIN, J. T. \& KIM, Y. W. 2016. An Exploration and Investigation of Edible Insect Consumption: The Impacts of Image and Description on Risk Perceptions and Purchase Intent. Psychology \& Marketing, 33, 94-112.

CLEMENT, J. 2007. Visual influence on in-store buying decisions: an eye-track experiment on the visual influence of packaging design. Journal of Marketing Management, 23, 917928.

COLlaVO, A., GLEW, R.H., HUANG, Y.S., CHUANG, L.T., BOSSE, R. \& PAOLETTI, M.G. 2005. House cricket small-scale farming. In M.G. Paoletti, ed., Ecological implications of minilivestock: potential of insects, rodents, frogs and snails, 519-544

DEROY, O., READE, B. \& SPENCE, C. 2015. The insectivore's dilemma, and how to take the West out of it. Food Quality and Preference, 44, 44-55.

GRUNERT, K. G. 2005. Food quality and safety: consumer perception and demand. European Review of Agricultural Economics, 32, 369-391.

HEISKANEN, E., HYVÖNEN, K., NIVA, M., PANTZAR, M., TIMONEN, P. \& VARJONEN, J. 2007. User Involvement in radical innovation: are consumers conservative? EUROPEAN JOURNAL OF INNOVATION MANAGEMENT, 10, 489509.

HOUSE, J. 2016. Consumer acceptance of insect-based foods in the Netherlands: Academic and commercial implications. Appetite, 107, 47-58.

HOUSE, J. 2018. Modes of Eating and Phased Routinisation: Insect-Based Food Practices in the Netherlands. Sociology, 53, 451-467.

HOUSE, J. 2018b. Public acceptance of insects as food in the Netherlands. Doctor of Philosophy PhD thesis, University of Sheffield.

JOUTSELA, M. 2010. Multisensory Persuasion and Storytelling through Packaging Design. IAPRI International Association of Packaging Research Institutes.

KAUPPI, S.-M. 2016. Insect economy and marketing: How much and in what way could insects be shown in packaging? Master's thesis at Aalto University.

KAUPPI, S.-M., PETTERSEN, I. N. \& BOKS, C. 2019. Consumer acceptance of edible insects and design interventions as adoption strategy. International Journal of Food Design, 4, 39-62.

LENSVELT, E. J. \& STEENBEKKERS, L. P. 2014. Exploring Consumer Acceptance of Entomophagy: A Survey and Experiment in Australia and the Netherlands. Ecol Food Nutr, 53, 543-561.

LOOY \& WOOD 2006. Attitudes toward invertebrates: are educational "bug banquets" effective? The Journal of Environmental Education, 37, 37-48.

MADDEN, T. J., HEWETT, KELLY., ROTH, MARTIN S., 2000. Managing Images in Different Cultures: A Cross-National Study of Color Meanings and Preferences. Journal of International Marketing, 8, 90-107.

MANCINI, S., MORUZZO, R., RICCIOLI, F. \& PACI, G. 2019. European consumers' readiness to adopt insects as food. A review. Food Research International, 122, 661678.

MIGLIETTA, P. P., DE LEO, F., RUBERTI, M. \& MASSARI, S. 2015. Mealworms for Food: A Water Footprint Perspective. Water, 7, 6190-6203.

ONWEZEN, M. C., VAN DEN PUTTELAAR, J., VERAIN, M. C. D. \& VELDKAMP, T. 2019. Consumer acceptance of insects as food and feed: The relevance of affective factors. Food Quality and Preference, 77, 51-63.

OONINCX, D. G., VAN ITTERBEECK, J., HEETKAMP, M. J., VAN DEN BRAND, H., VAN LOON, J. J. \& VAN HUIS, A. 2010. An exploration on greenhouse gas and ammonia production by insect species suitable for animal or human consumption. PLoS One, 5, e14445. 
ORTH, U. R. \& MALKEWITZ, K. 2008. Holistic Package Design and Consumer Brand Impressions. Journal of Marketing, 72, 64-81.

PILDITCH, J. 1961. The Silent Salesman: How to Develop Packaging that Sells, Business Publications.

PIQUERAS-FISZMAN, B. \& SPENCE, C. 2011. Crossmodal correspondences in product packaging. Assessing color-flavor correspondences for potato chips (crisps). Appetite, 57, 753-757.

RUNDH, B. 2005. The multi-faceted dimension of packaging: Marketing logistic or marketing tool? British Food Journal, 107, 670-684.

RUNDH, B. 2009. Packaging design: creating competitive advantage with product packaging. British Food Journal, 111, 988-1002.

SCHOUTETEN, J. J., DE STEUR, H., DE PELSMAEKER, S., LAGAST, S., JUVINAL, J. G., DE BOURDEAUDHUIJ, I., VERBEKE, W. \& GELLYNCK, X. 2016. Emotional and sensory profiling of insect-, plant- and meat-based burgers under blind, expected and informed conditions. Food Quality and Preference, 52, 27-31.

SHELOMI, M. 2015. Why we still don't eat insects: Assessing entomophagy promotion through a diffusion of innovations framework. Trends in Food Science \& Technology, 45, 311318.

SILAYOI, P. \& SPEECE, M. 2007. The importance of packaging attributes: A conjoint analysis approach. European Journal of Marketing, 41, 1495-1517.

TAN, H. S. G., VERBAAN, Y.T. AND STIEGER, M. 2017. How will better products improve the sensory-liking and willingness to buy insect based foods? Food Research International, 92, 95-105.

UNDERWOOD, R. 2003. The Communicative Power of Product Packaging: Creating Brand Identity via Lived and Mediated Experience. The Journal of Marketing Theory and Practice, 11, 62-76.

VAN HUIS, A., VAN ITTERBEECK, J., KLUNDER, H., MERTENS, E., HALLORAN, A., MUIR, G., \& VANTOMME, P. 2013. Edible insects: Future prospects for food and feed security. FAO Forestry Paper 171.

VERBEKE, W. 2015. Profiling consumers who are ready to adopt insects as a meat substitute in a Western society. Food Quality and Preference, 39, 147-155

VERNEAU, F., LA BARBERA, F., KOLLE, S., AMATO, M., DEL GIUDICE, T. \& GRUNERT, K. 2016. The effect of communication and implicit associations on consuming insects: An experiment in Denmark and Italy. Appetite, 106, 30-6.

ZEITHAML, V. 1988. Consumer Perceptions of Price, Quality and Value: A Means-End Model and Synthesis of Evidence. Journal of Marketing, 52, 2-22. 